\title{
POLA GEOMETRI PADA SENI DAN ARSITEKTUR ISLAM DI ANDALUSIA
}

Andi Pramono

Department of Architecture, Universidad de Sevilla,

Spanyol

e-mail: pramono.andi@gmail.com

\begin{abstract}
The most famous Islamic cultural heritages is the use of geometric patterns in Islamic art and architecture. This can be seen from the historical buildings that still exist in Alhambra which is located in Granada city, Andalucia, southern Spain. The way to make a layout plan, fasade, and ornaments that decorate the buildings were arranged in a simple mathematical art. The designing and building technique of Alhambra is based on geometry with the $1: 5$ ratio method.
\end{abstract}

Keywords: Islamic art, geometry, Alhambra

\begin{abstract}
Abstrak
Salah satu warisan budaya Islam yang terkenal adalah penggunaan pola geometri pada kesenian dan arsitektur Islam. Hal ini bisa dilihat dari bangunan sejarah yang masih ada di Alhambra yang terletak di kota Granada, Andalucia, Spanyol bagian selatan. Pola pembuatan denah, fasade, dan ornament yang menghiasi bangunan ditata dalam kesenian matematika sederhana. Desain dan teknik pelaksanaan bangunan tersebut didasarkan pada ilmu geometri dengan metode rasio 1:5.
\end{abstract}

Kata kunci: seni Islami, geometri, Alhambra

\section{Pendahuluan}

Islam pernah mengalami kejayaan di Eropa yang dimulai dari Andalusia, Spanyol bagian selatan, pada masa pemerintahan bani Umayah yaitu tahun 711 Masehi atau 97 Hijriah. Salah satu bangunan terkenal yang menjadi saksi kejayaan itu adalah Alhambra yang terletak di kota Granada dan Masjid Cordoba yang terletak di Cordoba. Kedua kota tersebut berada di Andalusia, Spanyol. Pembangunan kedua bangunan tersebut didesain tidak lepas dari seni Islam yang berkembang pada saat itu. Kesenian islam yang dimaksud, menurut Prisse dalam Rabah ${ }^{1}$ terbagi dalam tiga bagian, yaitu bunga, geometri, dan kaligrafi.

Ketiga seni Islam tersebut yang menghiasi ruang dalam dan fasade bangunan. Ketiga kesenian itu terbentuk karena adanya larangan dalam islam yang menampilkan sosok manusia dan hewan pada sebuah lukisan, pahatan dinding, ataupun dalam bentuk patung. Untuk memberikan dekorasi pada bangunan tanpa meninggalkan unsur seni, maka muncullah kesenian tersebut. Ketiga seni tersebut terkadang berdiri sendiri, dan terkadang berkolaborasi antar ketiganya. Pada bangunan-bangunan Islam di Andalusia, implementasi seni geometri lebih dominan dibandingkan dengan dua kesenian yang lain. Begitu juga pada teknik pembuatan denah, fasad, dan ornamen-ornamen yang menghiasi interior bangunan, teknik geometri sangat ditekankan sehingga kesan simetris sangat terlihat.

\section{Metode Pembangunan Alhambra}

Alhambra yang merupakan salah satu bangunan peninggalan Islam dinasti Nasrid di Granada, Spanyol, merupakan bangunan muslim yang didesain dengan ilmu matematika sederhana. Desain dan teknik pelaksanaan bangunan tersebut didasarkan pada ilmu geometri, tanpa dibekali dengan ilmu mekanik yang umum saat ini. Metode yang digunakan untuk pembuatan bangunan ini adalah metode rasio 1:5.

Metode rasio ini sering digunakan pada pembuatan bangunan-bangunan untuk penentuan denah yaitu perbandingan panjang dan lebar. Selain itu aspek rasio ini juga berlaku untuk ketinggian, yaitu perbadingan lebar dan tinggi bangunan. Sebagai contoh bangunan yang mengaplikasikan aspek rasio ini adalah denah bangunan Palacio del Parta di Alhambra dan menara Abd Al-Rahman III di Masjid Cordoba yang tinggi menaranya lima kali tinggi bangunan. Metode lain yang digunakan untuk pembuatan bangunan tersebut adalah teorema pitagoras yang berasal dari Yunani dan sedang berkembang saat itu. Teori ini memberikan pengaruh yang sangat kuat terhadap metode pembangunan Alhambra. Arsitek saat itu tidak menggunakan busur untuk menentukan sudut, melainkan memanfaatkan diagonal pada segitiga. Pemanfaatan diagonal tersebut untuk digunakan pada salah satu sisi segitiga akan menghasilkan sudut yang berbeda. Dengan demikian, akan didapatkan dua segitiga yang sering digunakan dengan sudut $90,45,45$, atau disebut 
dengan escuadra dan sudut 90,60,30, atau disebut dengan cartabon (Gambar 1).
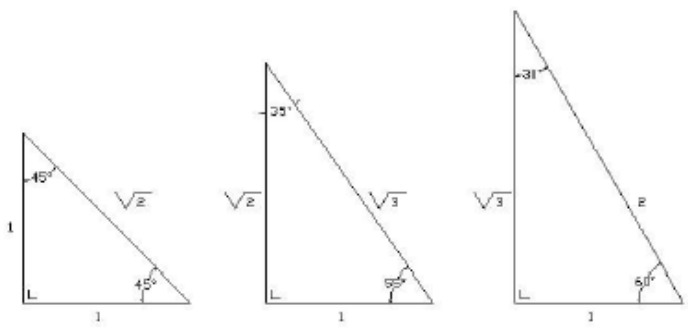

Gambar 1. Escuadra dan Cartabon

Sementara itu, untuk sistem satuan pada saat itu sudah mengenal Hispano-Muslim codo yang merupakan warisan Roman Pedes. Ada dua macam satuan yang dikenal pada saat itu, yaitu ma'munit codo yang bernilai antara $47,5 \mathrm{~cm}$ dan $50 \mathrm{~cm}$ dan rashshashid codo yang bernilai $60 \mathrm{~cm}$ dan $63 \mathrm{~cm}$ atau $62 \mathrm{~cm}$ dan $63 \mathrm{~cm}$. Untuk pembangunan Alhambra sendiri, sistem satuan yang digunakan adalah rashshashid codo.

\section{Implementasi Geometri pada Denah, Fasade, dan Layout di Alhambra}

Dalam penentuan sebuah denah, hal pertama yang diperhatikan adalah ratio perbandingan 1:5 (Gambar 2), yaitu lebar bangunan lima kali dari ukuran panjang. Pada contoh ini, kita mencoba mengacu pada bangunan Palacio del Partal. Mulamula dibuatlah bentuk persegi imajiner sejumlah 5 buah yang ditata secara menyamping. Selanjutnya dibuat garis luar untuk menentukan ketebalan dinding selebar $3 / 4$ rashshashid codo pada sisi timur, barat, dan selatan. Ukuran ini juga diberlakukan pada kolom masing-masing bagian persegi, kecuali pada bagian timur dan barat selebar 2 rashshashid codo karena digunakan untuk mengikat kolom dari dua arah.

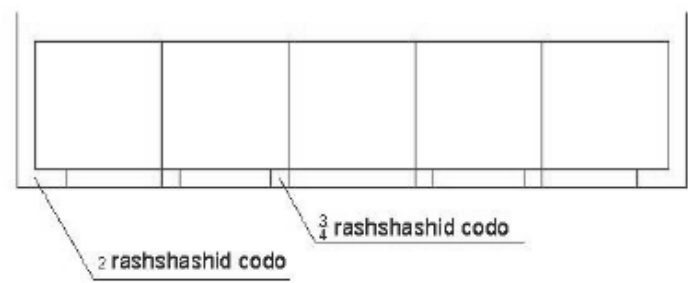

Gambar 2. Penentuan denah dengan ratio $1: 5$

Dengan menggunakan metode escuadra, ditariklah garis imajiner dari bagian dalam kolom 2 dan 4 sehingga menemukan satu titik di bagian utara. Titik itu jugalah yang menentukan ketebalan dinding bagian utara, sehingga dinding bagian utara bangunan tampak lebih tebal dari ketiga dinding yang lain (Gambar 3).

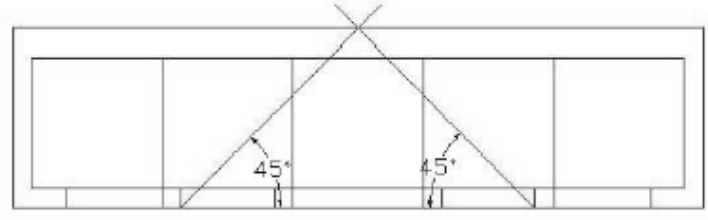

Gambar 3. Menentukan dinding utara dengan escuadra

Titik pertemuan yang digunakan untuk menentukan ketebalan dinding bagian utara, selanjutnya ditarik garis lurus menuju ke selatan. Dari titik bagian selatan tersebut dilanjutkan membuat garis imajiner dengan cartabon, yang menggunakan sudut $30^{\circ}$. Ketika garis imajiner menyentuh bagian dinding utara, maka akan terbentuk dua titik. Dari jarak kedua titik tersebut dibuat sebuah persegi dengan jarak yang sama. Persegi tersebut digunakan untuk sebuah tower (Gambar 4), sedangkan untuk ketebalan dinding menara di bagian barat dan timur, disamakan dengan ketebalan dinding bagian timur, selatan, dan barat pada galeri.

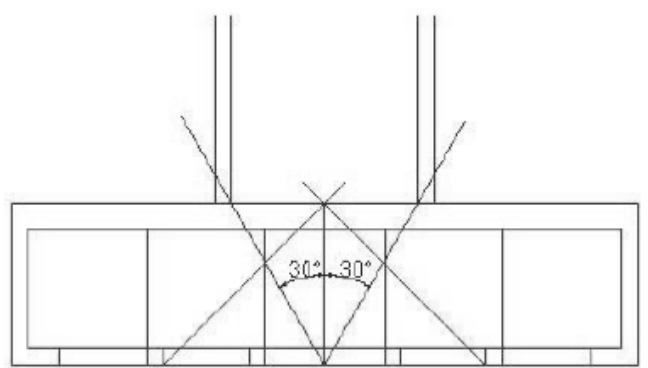

Gambar 4. Menentukan posisi tower dengan cartabon

Untuk ketebalan dinding bagian utara tower, ditentukan kembali dengan kombinasi escuadra dan cartabon, dan seterusnya. Langkah-langkah tersebut dalam sebatas rencana pada denah. Dalam menentukan kembali rancangan secara vertikal atau bentuk fasade, kembali digunakan escuadra dan cartabon (Gambar 5). Penentuan-penentuan tersebut dilakukan untuk mendapatkan proporsi yang tepat dalam sebuah bangunan. Tidak hanya pada bangunan, metode ini juga diterapkan dalam penentuan layout plan, misalnya taman Palacio del Riyad (Gambar 6).

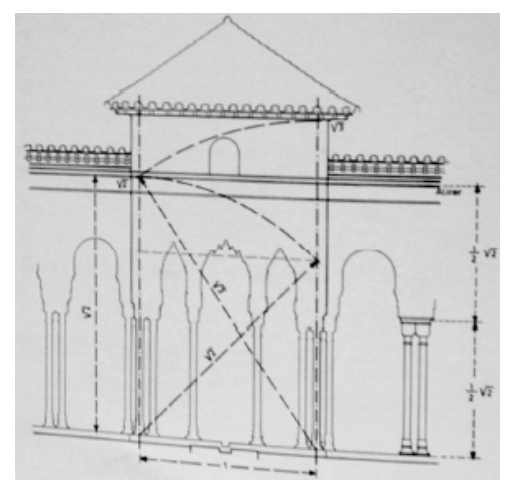

Gambar 5. Fasade bagian barat pavilion Palacio del Riyadh (Puertas) 


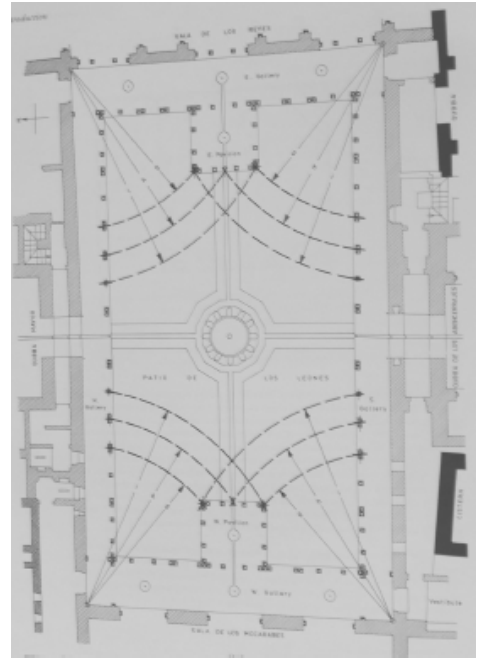

Gambar 6. Layout taman Palacio del Riyadh (Puertas)

\section{Implementasi Geometri pada Ornamen}

Bentuk dasar dalam pembuatan ornamen adalah lingkaran yang dikombinasikan dengan persegi dan lingkaran yang dikominasikan dengan segitiga. Pola geometri yang menggabungkan lingkaran dan persegi, disebut dengan sistem proporsi akar 2, karena pada pola ini menggunakan rasio perbandingan sisi persegi dengan diagonal persegi yaitu $1: \sqrt{2}$. Sementara itu, pola geometri yang menggabungkan lingkaran dan segitiga disebut dengan sistem proporsi akar 3, karena pada pola ini digunakan rasio perbandingan setengah alas dengan tinggi yang membagi dua segitiga sama sisi (Gambar 7).
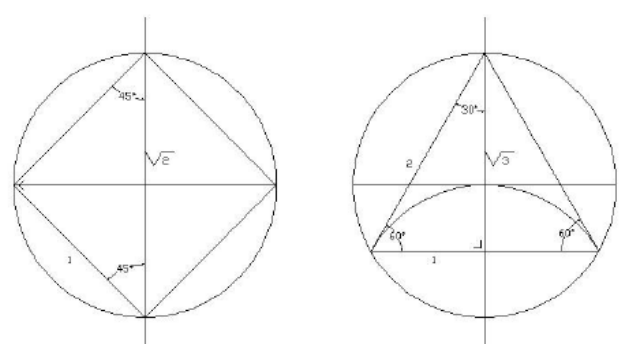

Gambar 7. Sistem proporsi $\sqrt{2}$ dan $\sqrt{ } 3$

Dari kedua sistem proporsi tersebut, dapat dilanjutkan dengan metode rotasi dan juga perpotongan garis. Selanjutnya didapatkan garisgaris imajiner yang dihasilkan dari rotasi obyek dan perpotongan garis yang menyentuhnya. Pada garisgaris imajiner itulah dibuatlah sebuah garis yang membentuk pola yang nantinya dapat diulang secara vertikal dan horisontal.

\section{Sistem Proporsi Akar 2}

Untuk membuat garis imajiner pada sistem proporsi akar 2, langkah pertama yang perlu dilakukan adalah membuat lingkaran dan membuat garis tegak lurus yang membagi lingkaran menjadi 4 bagian. Garis pembagi tersebut apabila bertemu dengan lingkaran akan terbentuk 4 titik temu. Selanjutnya dibuat empat lingkaran dengan radius yang sama dengan pusat lingkaran pada keempat titik temu tersebut. Dari perpotongan lingkaran-lingkaran tersebut akan didapatkan titik temu yang lain dan apabila dihubungkan akan didapatkan persegi di luar lingkaran dan garis diagonal (Gambar 8).
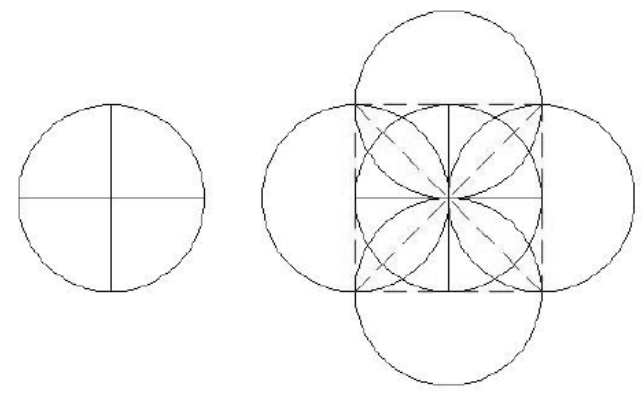

Gambar 8. Persegi dan garis diagonal sebagai modul dasar pembuatan garis imajiner pada sistem proporsi akar 2

Selanjutnya untuk membuat garis imajiner baru dapat dihasilkan dari titik-titik hasil perpotongan lingkaran, persegi, dan garis diagonal. Pada garisgaris imajiner itulah dimulai sebuah pola yang selanjutnya diulang secara vertikal dan horisontal. Pola pengulangan pada sistem proporsi ini adalah dengan mendekatkan persegi di luar lingkaran dengan persegi di luar lingkaran berikutnya (Gambar 9).

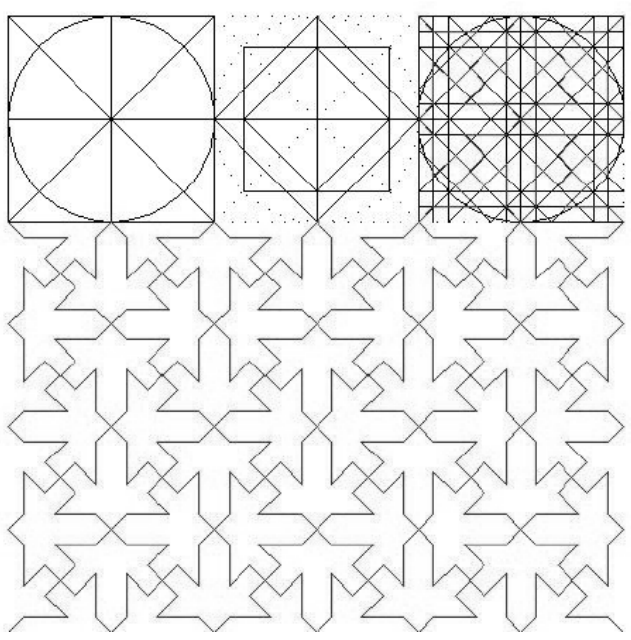

Gambar 9. Menggambar pola pada garis imajiner,dan pengulangan secara vertikal dan horizontal pada sistem proporsi akar 2

\section{Sistem Proporsi Akar 3}

Untuk pembuatan garis imajiner pada sistem proporsi akar 3, langkah pertama yang perlu dilakukan adalah membuat lingkaran dan membuat garis lurus yang membagi lingkaran menjadi 2 bagian. Selanjutnya dibuat lingkaran dengan pusat lingkaran pada kedua titik tersebut. Dari pertemuan kedua 
titik tersebut ditarik garis, sehingga terbentuk dua segitiga sama sisi dan atau heksagonal di dalam lingkaran (Gambar 10).
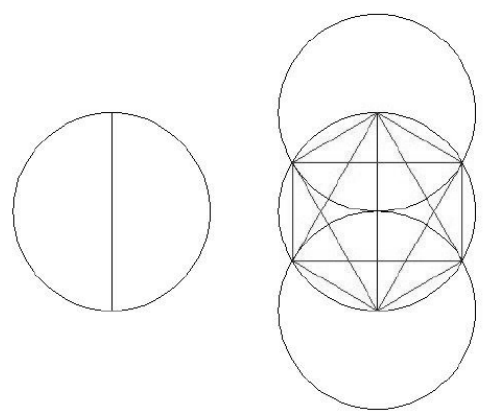

Gambar 10.Segitiga dan hexagonal sebagai modul dasar pembuatan garis imajiner $\mathrm{V}$ pada sistem proporsi akar 3

Dari garis-garis imajiner tersebut dapat dimulai sebuah pola dan dilakukan dengan pengulangan dengan cara mendekatkan modul-modul heksagonal. Berbeda dengan pengulangan pada sistem proporsi akar 2 yang dapat dilakukan secara linear baik horisontal ataupun vertikal karena pada sistem proporsi akar 2 memiliki bentuk persegi yang memiliki dua diagonal yang sama, pada heksagonal tidak memiliki diagonal yang sama (Gambar 11). Apabila pada sistem proporsi akar 3 dipaksakan untuk pengulangan secara linear seperti pada sistem proporsi akar 2, maka akan dihasilkan motif yang gagal sebab terdapat ruang kosong di antaranya (Gambar 12).

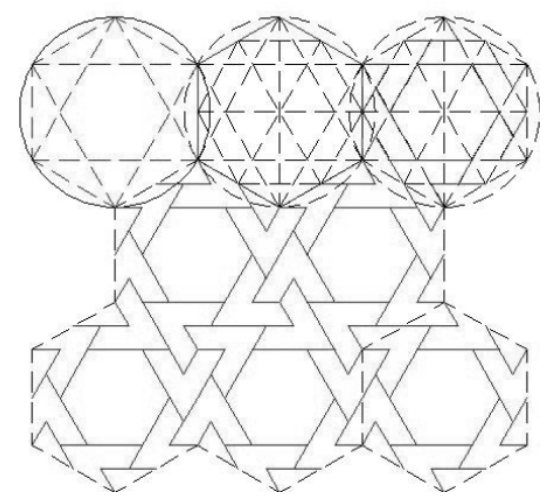

Gambar 11. Menggambar pola pada garis imajiner dan pengulangan secara vertikal dan horizontal pada sistem proporsi akar 3

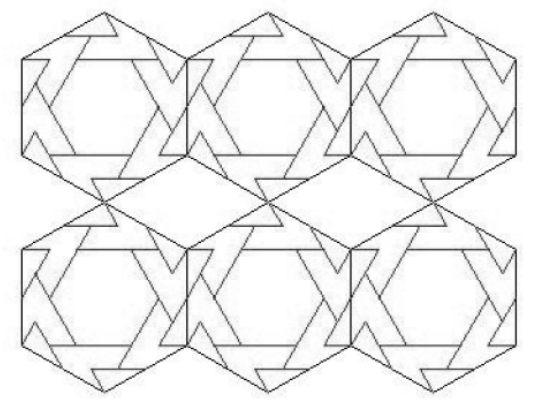

Gambar 12. Pola yang gagal karena pemaksaan pengulangan
Pola-pola yang terbentuk tersebut di atas, baik yang didapat dari sistem proporsi akar 2 ataupun akar 3, tidak hanya digunakan pada dekorasi arsitektur, tetapi juga pada kerajinan logam, kayu, keramik, tekstil, karpet, ataupun minatur.

\section{Penutup}

Dari beberapa contoh yang disebutkan di atas, yang meliputi langkah-langkah mendesain sebuah denah, fasad, layout, dan ornamen, dapat ditarik benang merah bahwa geometri yang merupakan bagian dari ilmu matematika memiliki andil yang besar dalam kesenian dan arsitektur Islam pada saat itu di Spanyol. Keindahan yang terlihat dan menjadi saksi hingga saat ini di istana Alhambra, Spanyol, merupakan salah satu contoh peninggalan masyarakat muslim Spanyol dalam berkesenian dan berarsitektur di masa itu.

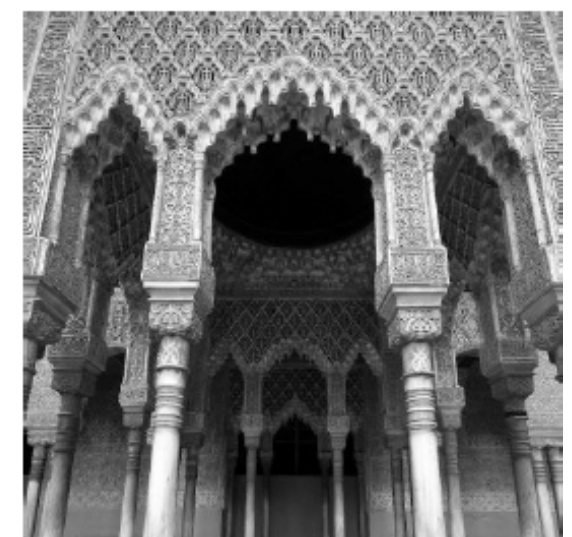

Gambar 13. Implementasi geometri pada fasade dan ornamen pada bangunan Alhambra (Sumber:Hawis Maduppa)

\section{References}

1 Rabah Saoud. 2004. Introduction to Muslim Art. London: FSTC.

2 Issam El-Said. 1993. Islamic Art and Architecture. The System of Geometric Design. United Kingdom: Garnet Publishing Limited.

3. Felix Escrig. 2009. Geometry and Structures. Historical Impressions about architecture. Valencia:J. IASS

4. Antonio Fernandez Puertas. 1997. The Alhambra from the Ninth Century to Yusuf I (1354).London: Saqi Books

5. The Metropolitan Museum of Art. 2004. Islamic Art and Geometric Design. New Jersey: Union Hill Printing Co., Inc. 